\title{
Radical scavenging activity of domestic fruit wine
}

\author{
Donghun Nam, Eunho Jang, Ki-Hyo Jang, Jae-Cheol Lee* \\ Department of Food and Nutrition, Kangwon National University, Samcheok 25913, Korea
}

\section{국산 과실주의 라디컬 소거능 활성}

\author{
남동훈·장은호·장기효·이재철* \\ 강원대학교 식품영양학과
}

\begin{abstract}
Domestic fruit wines, including apple, grape, Moru, and Korean black raspberry wines, contain a wide variety of phenolic compounds with different antioxidant activity. In this study, we established a simple and reliable on-line HPLC-ABTS assay system for determination of the antioxidative characteristics of fruit wines. The quantitative analytical assay of the antioxidative properties of fruit wines was carried out using an HPLC equipped with reverse-phase $C_{18}$ column, employing acetonitrile and water as gradient mobile phase at a flow rate of $0.4 \mathrm{~mL} / \mathrm{min}$ and a detection wavelength of UV $320 \mathrm{~nm}\left(1^{\text {st }}\right.$ detector) and UV $734 \mathrm{~nm}\left(2^{\text {nd }}\right.$ detector $)$. Among fruit wines, Moru wine showed the highest total phenolics and flavonoids content, as well as radical scavenging activity. The differences in radical scavenging activities were attributed to the structural differences in phenolic compound contents. In addition, between on-line HPLC-ABTS analysis and ABTS assay using a spectrophotometric assay gave a coefficient of determination $\left(R^{2}\right)$ of 0.9527 . All in all, the present study demonstrates that the established on-line HPLC-ABTS method is simple and reliable, and can thus be used for the determination of the antioxidative characteristics of fruit wines.
\end{abstract}

Key words : ABTS assay, antioxidant activities, on-line HPLC, radical scavenging activity, phenolic compounds

\section{서 론}

국내에서 생산되는 주요 과실은 감귤, 사과, 포도, 배 등 은 생과 형태로 소비되거나, 통조림, 주스, 잼, 와인 또는 음료 등의 가공식품으로 사용된다(1). 이들 과실류 중에서 복분자(Rubus coreansu, Korean black raspberry)와 머루 (Vitis amurensis, Moru)는 전체 식품가공용 사용량 대비 와 인 제조용 사용량이 각각 $75.8 \%$ 와 $73.6 \%$ 로 와인으로 가공 되는 비율이 높다. 포도(Table grape)는 연간 8,000-10,000 ton이 식품가공용으로 소비되고 전체 식품가공용 사용량 대비 주스 가공용 사용량과 와인 제조용 사용량은 각각 $63.2 \%$ 와 $9.0 \%$ 이다(1). 전체 식품가공용 포도 사용량 대비

*Corresponding author. E-mail : jclee033@kangwon.ac.kr Phone : 82-33-540-3311, Fax : 82-33-540-3319

Received 29 March 2018; Revised 6 April 2018; Accepted 24 May 2018.

Copyright (c) The Korean Society of Food Preservation. All rights reserved.
와인 가공용 포도 소비량이 낮은 이유는 국내산 포도가 대부분 생식용에 적합한 캠밸얼리나 거봉 등의 품종에 집중 된 것에서 기인한다. 이외에도 전체 식품가공용 사용량 대 비 와인으로 가공되는 비율이 높은 과종으로는 오디 $(59.1 \%)$ 와 단감 $(27.8 \%)$ 이 있으나 이들 과종의 전체 식품가 공용 사용량은 각각 262 ton과 108 ton으로 낮다. 전체 식품 가공용 사용량이 높은 과종으로는 감귤(91,126 ton), 사과 (28,087 ton), 유자(15,616 ton) 등이며 이들 과종의 와인 가공비율은 각각 $<0.1 \%, 2.1 \%$ 와 $0.1 \%$ 이다(1).

최근, 소득의 향상, 교통망 확충, 여가 시간의 증가 및 웰빙붐 등의 사회적 분위기에 편승하여 다양한 과실주들이 개발되고 있다(2-6). 과실주의 품질평가에서 관능적 특성 평가이외에도 기계적 분석에 기반한 이화학적 분석 $(\mathrm{pH}$, 산도, 당도, 유기산 및 무기질 함량과 조성, 향 특성, 아미노 산 조성) 결과와 항산화능 특성들이 과학적 자료로 사용된 다(2-7). 과실주 및 원료과실에서 항산화능 평가에는 Folin-Denis법에 기반한 비색정량을 원리로 하는 총 폴리페 놀 화합물 정량 $(7,8)$, 총 플라보노이드 함량 측정 $(9), \mathrm{DPPH}$ 
라디컬 소거능 측정(9), ABTS 라디컬 소거능 측정(9) 등의 방법들이 일반적으로 사용된다. 이러한 방법들은 신속하게 원료 과실 또는 와인발효 중 생성되는 항산화 물질들의 총량을 측정하는 장점이 있으나 정성적인 분석에는 제한점 이 있다. 최근에는 항산화 물질들의 정성적인 특성을 규명 을 위하여 on-line antioxidant assay 기술이 과실 또는 과실주 에 적용되고 있다(10-12). On-line antioxidant assay 기술은 HPLC 컬럼속으로 시료를 통과시켜 물질들을 분리시킨 후, 분리된 물질들이 ABTS 또는 DPPH 시약과 반응하도록 장 치하여 특정물질의 라디칼 소거능을 측정하는 장치로 구성 된다(10-12).

본 연구에서는 과종의 전체 식품가공용 사용량이 높으면 서 와인 가공비율이 높은 복분자, 머루, 포도를 포함하여 와인 가공비율은 낮지만 전체 식품가공용 사용량이 높은 사과를 대상으로 하여 이들 과실로 제조한 발효주의 항산화 특성을 분석하였다. 상업용 및 자체 제조한 4 가지 과실의 와인을 spectrophotometer를 사용한 비색법과 on-line HPLC-ABTS 분석법으로 분석하였으며 이들 방법들 간의 상관관계를 제시하였다.

\section{재료 및 방법}

\section{실험재료}

본 연구에 사용된 와인은 복분자, 사과, 머루와 포도 등 총 4 가지 과실을 원료로 제조하였으며, 이중 복분자 와인 2 종, 포도주 6종, 머루주 1 종 등 총 9 개 제품은 상업용 와인 을 지역마트에서 구매하여 $4^{\circ} \mathrm{C}$ 에서 냉장보관하면서 사용 하였다. 사과주 2 종과 머루주 1 종은 실험실에서 자체 양조 하였다. 사과(Fugi, Malus domestica)는 충북 제천산 생과를 사용하였다. 머루포도는 강원 삼척에서 수확된 머루포도 품종의 생과를 사용하였다. 사과와 머루포도는 줄기를 제 거한 후, 간단한 수세후 파쇄시켜 액체성분, 껍질과 씨앗부 분 모두를 원료로 사용하여 양조하였다. 설탕, potassium metabisulfite $\left(\mathrm{K}_{2} \mathrm{~S}_{2} \mathrm{O}_{5}\right)$, pectinase(pectinex 100L, 5,000 FDU/ $\mathrm{mL}$ )는 각각 제일제당(Seoul, Korea), Sigma-Adrich(St. Louis, MO, USA), Novozyme사(Bagsvaerd, Denmark) 제품을 사용 하였다. 효모는 Red star premier cuvee(Saccharomyces cerevisiae, LeSaffre, France)를 사용하였다. 항산화 실험에 사용한 시약과 표준물질인 Folin-Ciocalteu's phenol reagent, 갈산(gallic acid), 플라보노이드 측정용 시약(sodium nitrite, aluminum chloride hexa-hydrate, sodium hydroxide), 카테킨 하이드레이트((+)-catechin hydrate), 2,2'-azino-bis-3ethylbenzthiazoline-6-sulphonic acid(ABTS), potassium peroxodisulfate을 포함한 분석시약들은 Sigma-Aldrich사 제 품을 사용하였다.

\section{발효주 제조}

사과주와 머루주 제조를 위하여 착즙한 주스 $15 \mathrm{~L}$ 를 25 $\mathrm{L}$ 용량의 플라스틱 발효조에 첨가하고 설탕을 보당하여 $24{ }^{\circ} \mathrm{Brix}$ 로 조절하였다. 여기에 와인의 산화방지 및 발효중 오염 방지를 위하여 potassium metabisulfite 를 $1.5 \mathrm{~g}$ 첨가한 후, 상온에서 16 시간 동안 방치하여 내용물을 살균하였다. 살균 후 pectinase $5 \mathrm{~mL}$, 동결건조된 효모 $5 \mathrm{~g}$ 를 첨가하여 $23^{\circ} \mathrm{C}$ 에서 2 주 동안 정치발효하였다. 정치발효 기간 중 처음 7 일은 하루 2 차례, 다음 7 일은 하루 1 차례 발효액을 완전하 게 혼합하였다. 14일 발효 후에는 발효액에서 이산화탄소 의 발생이 현저하게 감소하였으며, 발효액을 여과하여 와 인을 분리하였다.

\section{항산화 활성 측정}

12 종 와인 시료의 총 폴리페놀 화합물의 함량측정은 페 놀성 및 비페놀성 환원물질이 Folin-Ciocalteu's phenol reagent에 반응하여 발색하는 원리를 바탕으로 하는 Folin-Denis법(8)에 의해 비색 정량하였다. 구체적으로, 시 료 $100 \mu \mathrm{L}$ 에 동량의 Folin-Ciocalteu's phenol reagent을 첨가 하여 실온에서 3 분 간 방치한 후, $200 \mu \mathrm{L}$ 의 $20 \% \mathrm{Na}_{2} \mathrm{CO}_{3}$ 을 가한 후 실온에서 90 분 동안 정치시켰다. 정치된 반응액을 원심분리기를 이용하여 $3,000 \mathrm{rpm}$ 에서 8 분간 원심분리를 한 후 상층액을 이용하여 $765 \mathrm{~nm}$ 로 설정된 microplate spectrophotometer(EON, BioTek, Winooski, VT, USA)으로 흡광도를 측정하였다. 시료에 포함된 환원물질들의 총량은 갈산(gallic acid)를 표준물질로 사용하여 환산하였다. 총 플라보노이드 함량은 플라보노이드(flavonoid)가 알칼리성 $\mathrm{pH}$ 조건에서 알루미늄(aluminum)과 반응하여 분홍색의 flavonoid-aluminum 결합체를 형성하는 원리를 활용하여 정량하였다(13). 증류수와 $1: 4$ 부피비로 희석한 와인시료 또는 표준물질((+)-catechin hydrate) $250 \mu \mathrm{L}$ 에 $15 \mu \mathrm{L} \mathrm{5 \%}$ sodium nitrite $\left(\mathrm{NaNO}_{2}\right), 30 \mu \mathrm{L} 10 \%$ aluminum chloride $\left(\mathrm{AlCO}_{3}\right.$ $\cdot 6 \mathrm{H}_{2} \mathrm{O}$ )를 연속적으로 첨가한 후, 다시 여기에 $100 \mu \mathrm{L} 1 \mathrm{M}$ sodium hydroxide $(\mathrm{NaOH})$ 와 $55 \mu \mathrm{L}$ 증류수를 가한 후 510 $\mathrm{nm}$ 에서 흡광도를 측정하였다. 시료중에 포함된 플라보노 이드 물질의 총량은 (+)-catechin hydrate를 표준물질로 사용 하여 농도를 나타내었다. 증류수에 녹인 catechin 표준용액 $(1 \mathrm{mM}, 0.5 \mathrm{mM}, 0.25 \mathrm{mM}, 0.625 \mathrm{mM}, 0.03125 \mathrm{mM}$ )를 사용 하였으며 획득된 calibration curve에 시료의 값들을 적용하 여 환산하였다. 모든 분석을 3회 분석하였다. ABTS 라디칼 소거활성(radical scavenging activity)은 비색 정량법과 on-line HPLC-ABTS 측정으로 나누어 측정하였다. 비색 정 량법은 $\operatorname{Re}$ 등(14)의 방법을 변형하여 측정하였다. 구체적으 로, $7.4 \mathrm{mM} \mathrm{ABTS}$ 용액을 제조한 후 여기에 potassium persulfate를 최종농도 $2.6 \mathrm{mM}$ 가 되도록 용해시킨 다음, 빛 이 들지 않은 암실에서 16시간 반응시켜 ABTS 시약을 제조 하였다. $\mathrm{ABTS}$ 시약은 흡광도 $734 \mathrm{~nm}$ 에서 측정하여 흡광도 
0.700 으로 조정하여 사용하였다. 와인시료 $20 \mu \mathrm{L}$ 를 취한 후 여기에 $\mathrm{ABTS}$ 시약 $180 \mu \mathrm{L}$ 를 가하여 실온에서 30 분 동안 방치하였다. 방치한 시료를 $734 \mathrm{~nm}$ 에서 흡광도를 측정하였 으며(A1), blank로는 와인시료 대신 증류수를 사용하여 위 에서 언급한 과정을 반복하여 흡광도 값을 측정하였다(A0). ABTS 라디칼 소거능은 blank 대비 시료의 감소된 흡광도의 비율로 계산되었다.

ABTS radical scavenging activity $(\%)=\left(1-\frac{\mathrm{A} 1}{\mathrm{~A} 0}\right) \times 100$

\section{On-line HPLC-ABTS 측정}

12 종 와인시료의 항산화 활성을 on-line HPLC-ABTS 장 치를 사용하여 $\mathrm{ABTS}$ 라디칼 소거능을 분석하였다(15). Potassium persulfate( $3.5 \mathrm{mM}$ in water)와 $\mathrm{ABTS}(2 \mathrm{mM}$ in water)를 제조한 후, 여기에 물을 가하여 8 배로 희석하여 갈색병에 담아 빛을 피할 수 있는 어두운 장소에서 16 시간 방치하여 $\mathrm{ABTS}$ 라디칼을 생성하였다. 이를 $\mathrm{ABTS}$ 시약으 로 사용하였다. 제조한 와인 시료 $20 \mu \mathrm{L}$ 를 $\mathrm{YMC}$ Hydrosphere $\mathrm{C}_{18}$ 컬럼(4.6×250 mm, $5 \mu \mathrm{L}$, Wilmington, $\left.\mathrm{NC}, \mathrm{USA}\right)$ 이 장착 된 HPLC(Agilent 1200, Agilent Technologies Inc., Santa Clara, CA, USA)에 주입하였다. 사용한 용매는 water와 acetonitrile $(\mathrm{ACN})$ 을 농도구배로 사용하여 시료 주입시점에 서 5분까지는 water: $\mathrm{ACN}=100: 0(\mathrm{v} / \mathrm{v}), 5-40$ 분 까지는 water:ACN=0:100로 증가시킨 후, 40-50분까지 용매조성이 유지되었고, 분석이 완료되면 water: $\mathrm{ACN}=100: 0$ 으로 변경 되었다. 분석기간 동안 용매의 유속은 $0.4 \mathrm{~mL} / \mathrm{min}$ 였으며 첫 번째 검출기의 파장은 $320 \mathrm{~nm}$ 로 설정하여 페놀성 물질 들을 분석하였다(Fig. 1). 첫 번째 검출기를 통과한 물질들 이 두 번째 펌프로부터 $0.2 \mathrm{~mL} / \mathrm{min}$ 의 유속으로 공급된 ABTS radical 시약과 만나서 radical 소거반응이 이루어 지 도록 하였으며 와인시료에서 생성된 성분들에 의한 라디컬 감소를 두 번째 검출기(파장 $734 \mathrm{~nm}$ )에서 측정하였다.

\section{통계처리}

실험결과는 3회 반복하여 측정한 값을 평균(mean)과 표 준편차(SD)로 표시하였고, 실험결과의 통계적 유의성 분석 을 위하여 1-way ANOVA-test를 사용하였고(16), 시료간의 유의성 평가는 Duncan's multiple range test를 실시하여 검 증하였다.

\section{결과 및 고찰}

\section{총 폴리페놀 및 총 플라보노이드 함량}

총 폴리페놀과 총 플라보노이드 함량을 측정한 결과는 Table 1과 같다. 와인 종류에 따른 총 폴리페놀 함량은 상업
용 복분자주가 $91.7 \mathrm{GAE} \mu \mathrm{g} / \mathrm{mL}$ 으로 상업용 머루와인 $(1,369.0 \mathrm{GAE} \mu \mathrm{g} / \mathrm{mL})$ 에 비하여 유의적으로 낮은 함량을 보였으며, 사과주(337.5-357.0 GAE $\mathrm{\mu g} / \mathrm{mL})$ 와 유사한 결과 를 보였다 $(\mathrm{p}<0.05)$. 포도주의 경우에는 총 폴리페놀 함량이 161.7-1,477.9 GAE $\mu \mathrm{g} / \mathrm{mL}$ 로 제품별로 큰 차이를 보였다. Hwang와 Park의 연구(7)에서는 Muscat Bailey A 포도과즙 을 동결농축 방법으로 농축하여 보당과정없이 양조시 포도 주의 총 폴리페놀 함량이 1,520-1,560 $\mu \mathrm{g} / \mathrm{mL}$ 수준으로 나타 났다. 한편, 동일한 분석조건에서 농도를 달리한 5 점의 gallic acid 표준물질로 측정 시 gallic acid(농도 구간 0.03-0.5 $\mathrm{mM}, \mathrm{X}$ 축$)$ 와 흡광도값( $\mathrm{A}_{765 \mathrm{~mm}}, \mathrm{Y}$ 축$)$ 의 관계식은 $\mathrm{Y}=3.51 \mathrm{X}+$ $0.05\left(\mathrm{R}^{2}=0.999\right)$ 로 나타났다. 와인 종류에 따른 총 플라보노 이드 함량은 상업용 복분자주가 107.4-169.0 CE $\mu \mathrm{g} / \mathrm{mL}$ 으로 상업용 머루와인(649.3-1,292.6 CE $\mathrm{gg} / \mathrm{mL})$ 에 비하여 유의 적으로 낮은 함량을 보였으며, 사과주(134.2-160.5 CE $\mu$ $\mathrm{g} / \mathrm{mL})$ 와 유사한 결과를 보였다 $(\mathrm{p}<0.05)($ Table 1$)$. 포도주의 경우에는 총 플라보노이드 함량이 $35.7-477.5 \mathrm{CE} \mu \mathrm{g} / \mathrm{mL}$ 로 제품별로 큰 차이를 보였다. 한편, 동일한 분석조건에서 농도를 달리한 5점의 catechin 표준물질로 측정 시 catechin (농도 구간 0.06-1.0 mM, X축)와 흡광도 값 $\left(\mathrm{A}_{510 \mathrm{~nm}}, \mathrm{Y}\right.$ 축)의 관계식은 $\mathrm{Y}=0.7033 \mathrm{X}-0.0068\left(\mathrm{R}^{2}=0.997\right)$ 로 나타났다. $\mathrm{Kim}$ 등(17)은 머루종자에는 플라바놀류(flavanol)의 일종인 catechin 함량이 $53 \mathrm{mg} / 100 \mathrm{~g}$ 수준으로 존재한다고 보고하 였다. 한편, Kang 등(18)은 머루와인의 총 플라보노이드 함량이 567-1,092 CE $\mu \mathrm{g} / \mathrm{mL}$ 로 보고하였다.

Table 1. Total polyphenols and flavonoids content of various Korean fruits wine

\begin{tabular}{ccc}
\hline Wine & $\begin{array}{c}\text { Total polyphenols } \\
(\mathrm{GAE} \mu \mathrm{g} / \mathrm{mL})\end{array}$ & $\begin{array}{c}\text { Total flavonoids } \\
(\mathrm{CE} \mu \mathrm{g} / \mathrm{mL})\end{array}$ \\
\hline AW $(\mathrm{L}))^{1)}$ & $337.4 \pm 22.5^{2)(3)}$ & $160.5 \pm 8.0^{\mathrm{d}}$ \\
AW (L) & $357.0 \pm 2.9^{\mathrm{c}}$ & $134.2 \pm 7.9^{\mathrm{d}}$ \\
MW (L) & $3,476.9 \pm 487.6^{\mathrm{a}}$ & $1,292.6 \pm 40.7^{\mathrm{a}}$ \\
MW & $1,369.0 \pm 116.5^{\mathrm{b}}$ & $649.3 \pm 30.4^{\mathrm{b}}$ \\
GW & $161.7 \pm 5.5^{\mathrm{c}}$ & $417.0 \pm 126.0^{\mathrm{c}}$ \\
GW & $663.5 \pm 35.1^{\mathrm{c}}$ & $35.7 \pm 1.0^{\mathrm{d}}$ \\
GW & $232.8 \pm 14.6^{\mathrm{c}}$ & $477.5 \pm 31.1^{\mathrm{c}}$ \\
GW & $411.7 \pm 46.2^{\mathrm{c}}$ & $161.8 \pm 9.9^{\mathrm{d}}$ \\
GW & $1,477.9 \pm 141.0^{\mathrm{b}}$ & $117.0 \pm 7.9^{\mathrm{d}}$ \\
GW & $669.8 \pm 13.5^{\mathrm{c}}$ & $39.5 \pm 2.5^{\mathrm{d}}$ \\
KRW & $91.7 \pm 22.5^{\mathrm{c}}$ & $169.0 \pm 4.7^{\mathrm{d}}$ \\
KRW & $345.6 \pm 16.2^{\mathrm{c}}$ & $107.4 \pm 7.7^{\mathrm{d}}$ \\
\hline
\end{tabular}

${ }^{1)} \mathrm{AW}(\mathrm{H})$, lab-brewed apple wine; MW (L), lab-brewed Moru wine; MW, commercial Moru wine; GW, commercial grape wine; KRW, commercial Korean raspberry wine. ${ }^{2)}$ All values are mean $\pm \mathrm{SD}(\mathrm{n}=3)$.

3)a-d Means with different superscripts in the same column are significantly different at $\mathrm{p}<0.05$. 


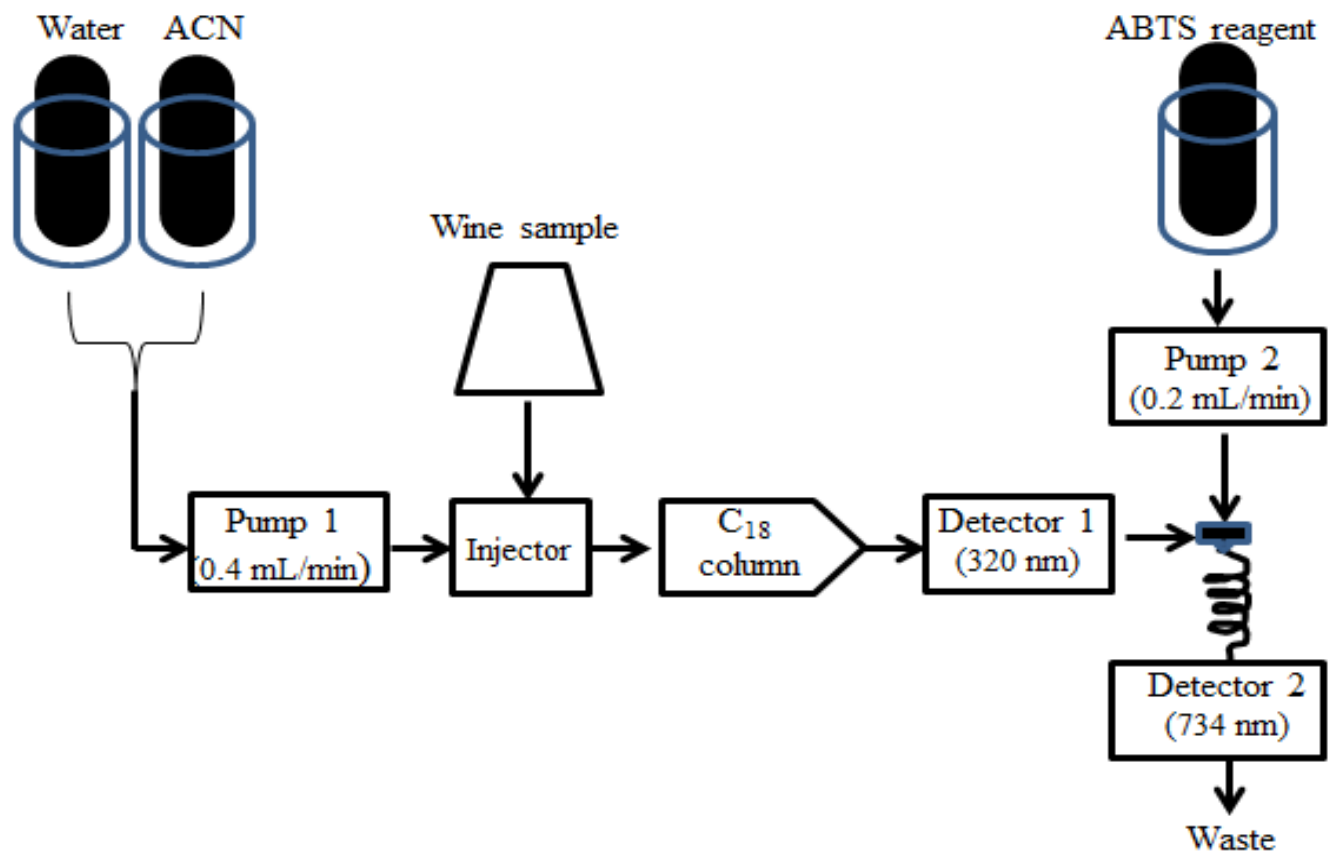

Fig. 1. The schematic diagram of on-line HPLC system.

\section{ABTS 라디컬 소거능}

비색법으로 ABTS 라디컬 소거능을 분석한 결과를 Table 2에 나타내었다. 사과주, 머루주, 포도주, 복분자주의 ABTS 라디컬 소거능은 각각 $13.7-14.2 \%, 54.5-89.6 \%, 7.5-48.2 \%$, 11.2-15.2\%로 나타나, 머루주의 ABTS 라디컬 소거능이 다

Table 2. ABTS free radical scavenging activity (ABTS) of various Korean fruits wine

\begin{tabular}{cc}
\hline Wine & ABTS $(\%)$ \\
\hline AW (L) $)^{1)}$ & $13.7 \pm 0.9^{2) \mathrm{ef} 3)}$ \\
AW (L) & $14.2 \pm 1.1^{\mathrm{e}}$ \\
MW (L) & $89.6 \pm 2.2^{\mathrm{a}}$ \\
MW & $54.5 \pm 2.9^{\mathrm{b}}$ \\
GW & $29.8 \pm 1.8^{\mathrm{d}}$ \\
GW & $8.0 \pm 0.7^{\mathrm{fg}}$ \\
GW & $48.2 \pm 1.3^{\mathrm{c}}$ \\
GW & $14.3 \pm 1.1^{\mathrm{e}}$ \\
GW & $9.8 \pm 0.1^{\mathrm{fg}}$ \\
GW & $7.5 \pm 1.3^{\mathrm{g}}$ \\
KRW & $15.2 \pm 0.8^{\mathrm{e}}$ \\
KRW & $11.2 \pm 0.5^{\mathrm{efg}}$ \\
\hline
\end{tabular}

${ }^{1)} \mathrm{AW}(\mathrm{L})$, lab-brewed apple wine; MW (L), lab-brewed Moru wine; MW, commercial Moru wine; GW, commercial grape wine; KRW, commercial Korean raspberry wine. ${ }^{2)}$ All values are mean $\mathrm{SD}(\mathrm{n}=3)$.

${ }^{3) a-g}$ Means with different superscripts in the same column are significantly different at $p<0.05$.
른 3종의 과실주보다 유의적으로 높게 나타났다 $(\mathrm{p}<0.05)$. Kang 등(18)의 연구에서는 숙성 1-3년산 머루와인의 자유 라디컬 포획효과는 80-87\% 내외로 합성 합성제인 BHA $(90 \%)$ 와 quercetin(92\%)와 유사한 수준으로 나타났다. 온라인(on-line) 항산화 분석장치를 활용하여 과실주 시료 들의 항산화 물질 탐색 및 항산화 활성을 측정하였다(Fig. 2). 이동상에 의해서 HPLC 칼럼에 주입된 시료는 칼럼을 통과하면서 순차적으로 분리되며, 분리된 순서에 따라 UV 검출기 $(320 \mathrm{~nm})$ 에서 정보가 수집된다. 검출기를 통과한 시 료는 이동상 $(0.4 \mathrm{~mL} / \mathrm{min})$ 에 의하여 이동하면서 $\mathrm{ABTS}$ 시약 을 $0.2 \mathrm{~mL} / \mathrm{min}$ 속도로 공급하는 관과 합류한다. 합류된 시료와 ABTS 시약은 $0.6 \mathrm{~mL} / \mathrm{min}$ 의 속도로 이동하면서 반 응하고 일정시간 후에는 두 번째 검출기 $(734 \mathrm{~nm})$ 에서 자유 라디컬 포획정도가 정량적으로 측정된다. 첫 번째 검출기 에서는 사용한 컬럼과 분석조건에서 나타나는 페놀성 화합 물과 다른 물질들이 HPLC 크로마토그램을 형성한다. 두 번째 검출기에서는 분석기간동안 $\mathrm{ABTS}$ 라디컬 수치가 최 대값을 유지된다. 첫 번째 칼럼에서 분리된 물질들이 ABTS 라디컬 소거능이 있으면 해당되는 물질이 두 번째 검출기를 통과하는 시점에 ABTS 라디컬 수치가 아래쪽으로 감소하 였다가 다시 최대값으로 복원된다. 연구자는 첫 번째 검출 기에서 획득된 크로마토그램과 두 번째 검출기에서 획득된 크로마토그램을 결합시켜서 나타나도록 프로그래밍한다 (19). 두 개의 크로마토그램을 동시에 확인함으로써 두 번째 검출기에서 확인된 $\mathrm{ABTS}$ 라디컬 소거능을 갖는 피크를 


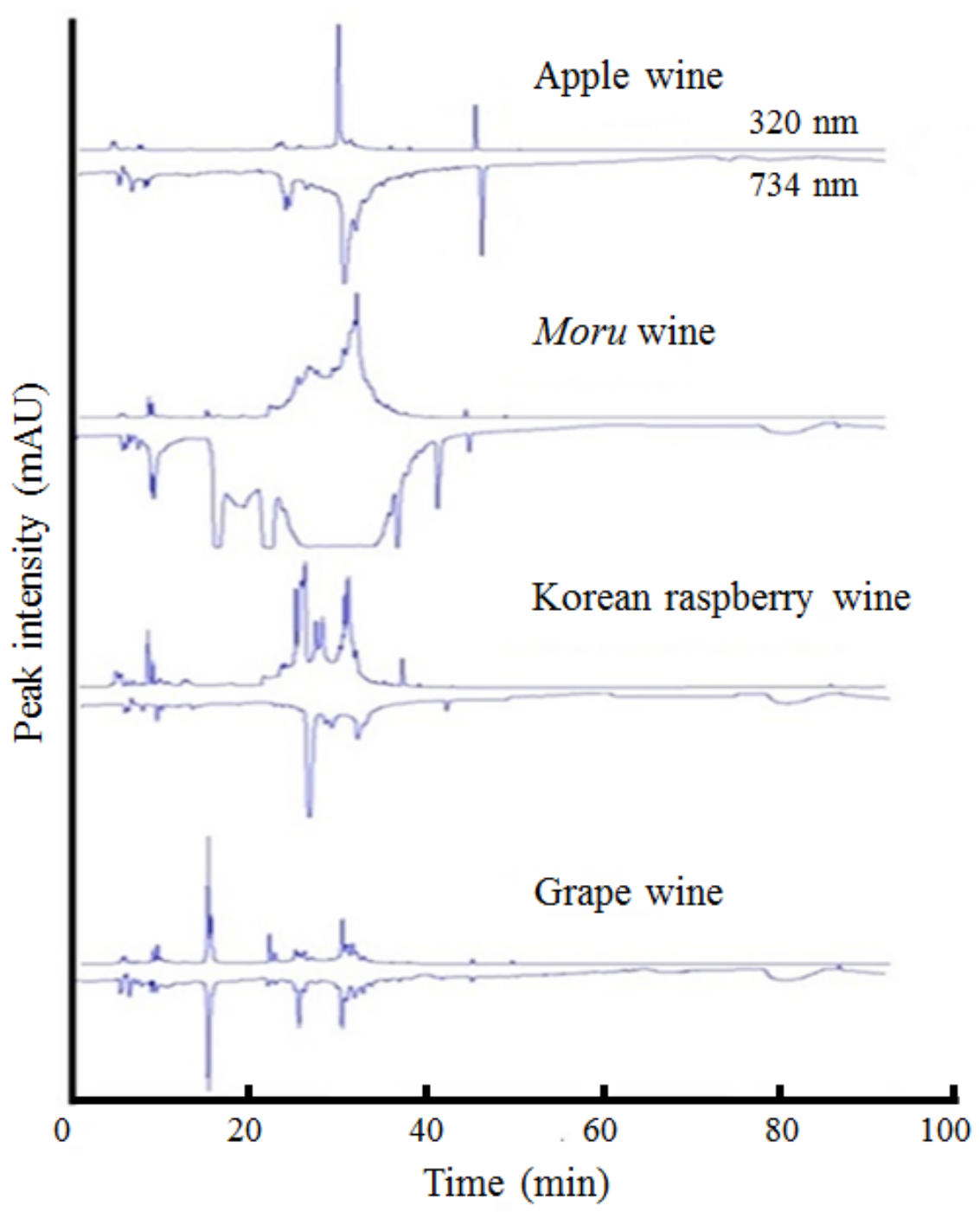

Fig. 2. On-line HPLC-ABTS analysis of each Korean fruits wine.

The HPLC chromatogram of samples was detected at positive peaks at $320 \mathrm{~nm}$ for phenolic compounds and the ABTS radical scavenging activity of each compound was seen at negative peaks at $734 \mathrm{~nm}$.

첫 번째 검출기에서 나타난 피크로 특정한다. 첫 번째 검출 기에서 나타난 피크의 물질을 확인한 후에 표준물질을 사용 하여 해당되는 피크의 정량분석이 가능해 진다. 한편, 두 번째 검출기에서 나타난 피크들은 면적 값을 분석기계가 자동적으로 제시함으로써 신뢰할 수 있는 ABTS 라디컬 소거능을 계산할 수 있다. 과실주 시료들을 온라인(on-line) 항산화 분석장치로 분석 시 두 번째 검출기에서 다수의 화합물들이 확인되어 과실주에 $\mathrm{ABTS}$ 라디컬을 감소시키 는 물질들이 다수 존재하는 것으로 확인되었다(Fig. 2). 특 히, 과실주의 종류가 동일한 경우, 정성적인 on-line HPLC-ABTS 분석 결과가 유사하게 나타났다. On-line HPLC-ABTS 분석 시 크로마토그램의 피크 다양성 측면에 서 4 가지 과실주 중에서 머루주 시료에서 가장 많은 수의
피크와 피크 면적이 확인되었다. 사과주의 경우에는 32-35 분대에서 $\mathrm{ABTS}$ 라디컬을 감소시키는 물질들이 가장 높게 나타난 반면, 복분자주의 경우에는 26-28분대에서 가장 높 아, 과실주별 대표적인 ABTS 라디컬을 감소시키는 물질들 이 차이가 있음을 보여준다. 항산화 활성은 원료 과실에 포함된 항산화 물질들이 직접 과실주에 반영되거나, 미생 물 발효에 의하여 항산화물질들이 다른 물질로 변할 수 있다. 사과의 경우에는 $100 \mathrm{~g}$ 의 과실에 비타민 $\mathrm{C}$ 가 $4 \mathrm{mg}$, 베타카로틴(ß-carotene)과 루테인(lutein) 등의 카로티노이 드류가 0.02-0.09 mg, 시아니딘(cyanidin)를 주성분으로 하 는 안토시아닌류(anthocyanidins)가 $0.76 \mathrm{mg}$, 에리오딕티올 (eriodictyol), 헤스페레틴(hesperetin), 나린제닌(naringenin) 등의 플라바논류(flavanone)가 $<1 \mathrm{mg}$, 플라바놀류(flavanol) 
중에서 카테킨류(catechins)인 카테킨(catechin)이 $0.7-22 \mathrm{mg}$, 에피카테킨(epicatechin)이 $5.21-18.80 \mathrm{mg}$, 에피갈로카테킨 (epigallocatechin)이 0.25-111.0 mg, 플라바놀류(flavanol) 중 에서 프로안토시아니딘류(proanthocyanidins)가 84.1-91.3 $\mathrm{mg}$, 플라본류(flavones)로 루테올린(luteolin)이 $0-0.17 \mathrm{mg}$, 플라보놀류(flavonols)로 비배당체인 캠퍼롤(kaempferol)이 0-0.02 mg, 미리세틴(myricetin)이 0-0.01 mg, 퀘세틴 (quercetin)이 0.13-11.0 mg, 플라보노이드류(flavonoides) 중 에서 이소플라본(isoflavones)이 $0.14-0.25 \mathrm{mg}$, 페놀산류 (phenolic acids) 중에서 protocatechuic acid가 0-0.49 mg, 페놀산류 중에서 하이드록시벤조산류(hydroxybenzoic acid)로 카페익산(caffeic acid)이 0-67.75 mg, 클로로겐산 (chlorogenic acid)이 7.06-32.80 mg, 계피산(cinnamic acid) 이 0.06-0.40 mg, 페룰린산(ferulic acid)이 0-4.95 mg, p-쿠마 르산(p-coumaric acid)이 $0.29-23.75 \mathrm{mg}$ 존재한다. 복분자의 경우에는 $100 \mathrm{~g}$ 의 과실에서 카로티노이드류 중 베타카로틴 이 $0.13 \mathrm{mg}$, 루테인이 $0.12 \mathrm{mg}$, 안토시아닌류로 시아니딘이 $90.31 \mathrm{mg}$, 펠라고니딘이 $0.15 \mathrm{mg}$, 플라바놀류 중에서 카테 킨류인 카테킨이 0.72-37.06 mg, 에피카테킨이 4.66-11.48 $\mathrm{mg}$, 에피갈로카테킨이 $0.1-0.15 \mathrm{mg}$, 플라바놀류 중에서 프 로안토시아니딘류가 $15.7 \mathrm{mg}$, 플라보놀류로 캠퍼롤이 0.06 $\mathrm{mg}$, 미리세틴이 $0.67 \mathrm{mg}$, 퀘세틴이 $1.76 \mathrm{mg}$, 페놀산류 중 클로로겐산이 $0.1 \mathrm{mg}$, 엘라그산이 $31.9-43.7 \mathrm{mg}$ 발견된다 (20). 포도의 경우에는 $100 \mathrm{~g}$ 의 과실에서 카로티노이드류인 베타카로틴이 $0.11-0.15 \mathrm{mg}$, 루테인이 $0.18-0.39 \mathrm{mg}$, 안토시 아닌류로 시아니딘이 $1.18-34.19 \mathrm{mg}$, 델피니딘이 $1.82-3.17$ $\mathrm{mg}$, 펠라고니딘이 $0-2.96 \mathrm{mg}$, 말비딘이 $58.8 \mathrm{mg}$, 페오니딘 이 $6.13 \mathrm{mg}$, 페튜니딘이 $2.81 \mathrm{mg}$, 플라바놀류 중에서 카테킨 류인 카테킨이 5.46-10.14 mg, 에피카테킨이 $5.24-8.68 \mathrm{mg}$, 에피갈로카테킨이 0-0.03 mg, 플라바놀류 중에서 프로안토 시아니딘류가 $60.4 \mathrm{mg}$, 퀘세틴이 $2.54 \mathrm{mg}$, 플라보노이드류 중 이소플라본류가 $0.08 \mathrm{mg}$, 페놀산류 중 몰식자산(gallic acid)이 $375 \mathrm{mg} / 100 \mathrm{~g}$, protocatechuic acid가 $53.5 \mathrm{mg} / 100$ $\mathrm{g}$, 탄닌산(tannic acid)이 $40 \mathrm{mg}$, 클로로겐산이 $6.3 \mathrm{mg}$ 존재 한다(20).

원료 과실에 존재하는 항산화 물질의 다양성이 과실주에 반영되어 다양한 항산화물질로 on-line HPLC ABTS 분석에 반영된 것으로 판단된다(Fig. 2). 과실주의 on-line HPLC$\mathrm{ABTS}$ 분석결과와 항산화 활성의 상관관계를 회기 분석한 결과, 총 페놀, 총 플라보노이드 함량, 비색법에 의한 $\mathrm{ABTS}$ 라디컬 소거능의 상관계수 $\left(\mathrm{R}^{2}\right)$ 가 각각 $0.6388,0.9150$, 0.9527로 나타났다(Fig. 3). 이러한 결과는 on-line HPLC-ABTS 분석이 과실주의 $\mathrm{ABTS}$ 라디컬 소거능 측정에 사용될 수 있음을 나타낸다. 비색법에 의한 ABTS 라디컬 소거능 측정 은 ABTS 라디컬 소거능 총량을 나타낸 반면, on-line HPLC-ABTS 분석은 ABTS 라디컬 소거능을 대표하는 지 표물질을 특정하는 장점이 있다 $(19,21)$. 사과주의 주요 항
산화물질 함량을 분석한 연구에서는 사과주 $100 \mathrm{~mL}$ 에 클로 로겐산이 7.1-9.2 mg, 에피카테킨이 $2.3-4.0 \mathrm{mg}$ 존재하는 것으로 나타난 반면, 카테킨, 카페익산, $\mathrm{p}$-쿠마르산은 각각 $<0.1 \mathrm{mg}$ 으로 정량되어 사과와 사과주의 주요 항산화물질 구성에서 큰 차이가 있었다(22). 결론적으로, on-line HPLC$\mathrm{ABTS}$ 분석 결과로 판정 시, 각종 과실주의 항산화 활성 중 ABTS 라디컬 소거능은 다양한 항산화 물질들로 특징되 며, 본 연구에 사용된 4종류의 과실주 중에서 머루주의 ABTS 라디컬 소거능이 가장 높게 나타났다. 본 연구에 사용된 on-line HPLC-ABTS 분석은 mass spectrophotometer

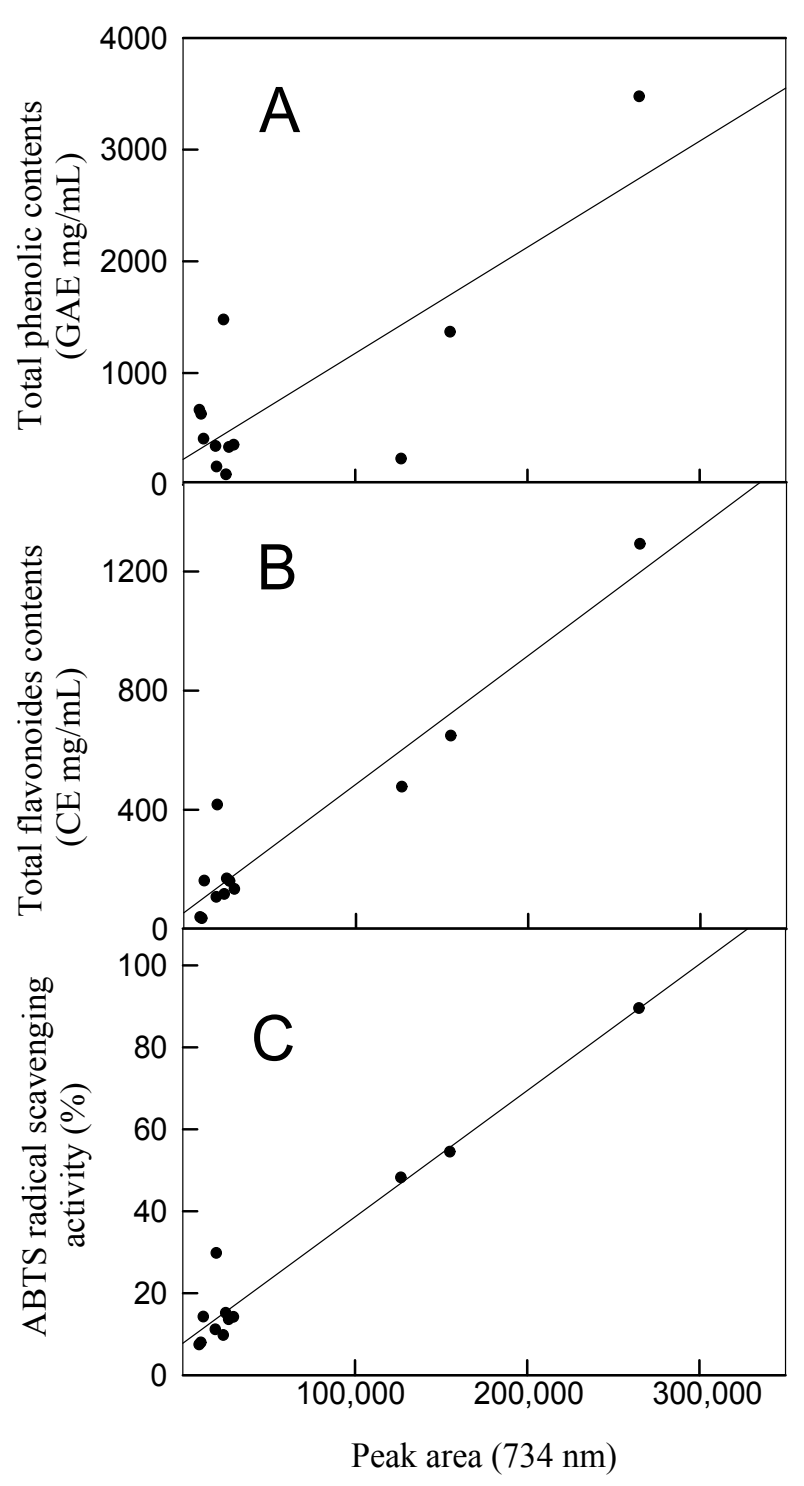

Fig. 3. Correlation relationship between spectrophotometric measurement and on-line HPLC-ABTS analysis at $734 \mathrm{~nm}$.

A, total polyphenols (Y axis) vs on-line HPLC-ABTS assay ( $\mathrm{X}$ axis); B, total flavonoids ( $\mathrm{Y}$ axis) vs on-line HPLC-ABTS assay (X axis); C, ABTS free radical scavenging activity ( $\mathrm{Y}$ axis) vs on-line HPLC-ABTS assay ( $\mathrm{X}$ axis). 
와 연계 시 과실주의 $\mathrm{ABTS}$ 라디컬 소거능 활성을 대표하는 지표물질의 함량 측정에 도움을 줄 것으로 예상된다.

\section{요 약}

국산 과실주인 사과주, 포도주, 머루주, 복분자주는 다양 한 항산화 활성을 가지고 있다. 본 연구는 이들 과실주의 라디컬 소거능 활성을 on-line HPLC-ABTS 분석법으로 유 효성 검증을 실시하고자 하였다. HPLC에 연결된 컬럼을 통과한 시료의 페놀성 물질의 정량분석은 $320 \mathrm{~nm}$ 로 설정된 첫 번째 검출기에서 실시하였고, 연속적으로 $\mathrm{ABTS}$ 라디컬 소거능 활성은 $734 \mathrm{~nm}$ 로 설정된 두 번째 검출기에서 확인 되었다. 과실주 종류별 항산화 활성 측정시 비색법으로 측 정한 총 페놀 함량, 총 플라보노이드 함량, $\mathrm{ABTS}$ 라디컬 소거능 활성 측면에서 머루주에서 가장 높게 나타났다. On-line HPLC-ABTS 분석법으로 분석 시 과실주 종류별 $\mathrm{ABTS}$ 라디컬 소거능 활성을 나타내는 물질의 종류에서 차이가 있음을 확인하였으며, 비색법으로 측정한 $\mathrm{ABTS}$ 라디컬 소거능 활성 측정과 on-line HPLC-ABTS 분석법 사이의 상관성 $\left(\mathrm{R}^{2}\right)$ 을 측정시 0.9527 로 나타났다. 이상의 결 과, 과실주의 ABTS 라디컬 소거능에 대한 on-line HPLC$\mathrm{ABTS}$ 분석방법은 과실주의 $\mathrm{ABTS}$ 라디컬 소거능을 확인 하는데 적합한 방법으로 나타났다.

\section{감사의 글}

본 논문은 2016년도 강원대학교 대학회계 학술연구조성 비(관리번호-620160036)에 의해 수행되었습니다.

\section{References}

1. Kim YJ, Song KC, Lee YH, Jang KH, Jung ST, Jeong C (2012) Fruit wine: Science and application. Ministry for Food, Agriculture, Forestry and Fisheries, Suwon, Korea, p 350-364

2. Kim JS, Yun JH, Lee MR, Kim SH, Lee JH, Jang KH (2014) Effect of processing of Moru (Vitis amurensis) wine on clarification. Int J Fruit Sci, 14, 405-415

3. Han WC, Ji SH, Lee JC, Cheong C, Kang SA, Jang $\mathrm{KH}$ (2009) Quality characteristics of apple wine fermented with Rosa rugosa Thunb.. Korean J Food Preserv, 16, 311-316

4. Bang BH, Jeong EJ, Kang H, Rhee MS, Yi DH, Paik JK (2017) Effects of fining treatments on color and clearness of apple wine. J Korean Soc Food Sci Nutr, $46,368-373$

5. Choi MH, Lee JS, Lim BS (2017) Effects of combination treatment with sulfur dioxide generating pad and modified atmosphere packaging (MAP) on the quality of 'Campbell Early' grape under simulated export conditions. Korean J Food Preserv, 24, 734-745

6. Yang HJ, Jeong SJ, Jeong SY, Heo JH, Jeong DY (2015) Screening of biogenic amine non-producing yeast and optimization of culture conditions using statistical method for manufacturing black raspberry wine. J Korean Soc Food Sci Nutr, 44, 592-601

7. Hwang SW, Park HD (2010) Properties of red wine fermented using freeze-concentrated Muscat Bailey A grape juice. Korean J Food Preserv, 17, 807-813

8. Amerine MA, Ough CS (1980) Methods for analysis of musts and wine. Wiley \& Sons, New York, NY, USA, p 176-180

9. Lee JE, Kim KM, Kim JS, Kim GC, Choi SY, Kim SB (2017) Chemical compositions and antioxidant activities depending on cultivation methods and various parts of yuza. Korean J Food Preserv, 24, 802-812

10. Nuengchamnog $N$, Ingkanian $K$ (2010) On-line HPLC-MS-DPPH assay for the analysis of phenolic antioxidant compounds in fruit wine: Antidesma thwaitesianum Muell. Food Chem, 118, 147-152

11. Karacelik AA, Kucuk M, Iskefiyeli Z, Aydemir S, Smet SD, Miserez B, Sandra P (2015) Antioxidnat components of Viburnum opulus L. determined by on-line HPLCUV-ABTS radical scavenging and LC-UV-ESI-MS methods. Food Chem, 175, 106-114

12. Zhang H, Xi W, Yang Y, Zhou X, Liu X, Yin S, Zhang J, Zhou Z (2015) An on-line HPLC-FRSD system for rapid evaluation of the total antioxidant capacity of Citrus fruits. Food Chem, 172, 622-629

13. Zhishen J, Mengcheng T, Jianming W (1999) The determination of flavonoid contents in mulberry and their scavenging effects on superoxide radicals. Food Chem, 64, 555-559

14. Re R, Pellegrini N, Pannala A, Yang M, Rice-Evans C (1999) Antioxidant activity applying an improved ABTS radical cation decolorization assay. Free Radical Biol Med, 26, 1231-1237

15. Lee JH, Kang TH, Um BH, Sohn EH, Han WC, Ji SH, Jang KH (2012) Evaluation of physicochemical and fermentation qualities of Moru wines supplemented with pine needles or medicinal herbs. J East Asian Soc Diet 
Life, 22, 886-894

16. Albright SC, Winston WL, Zappe C (1999) Data analysis and decision making with Microsoft Excel. Brooks/Cole Publishing Co, Pacific Grove, CA, USA, p 945-999

17. Kim NY, Choi JH, Kim YG, Jang MY, Moon JH, Park GY, Oh DH (2006) Isolation and identification of an antioxidant substance from ethanol extract of wild grape (Vitis coignetiea) seed. Korean J Food Sci Technol, 38, 109-113

18. Kang BT, Yoon OH, Lee JW, Kim SH (2009) Quantitative properties of wild grape wine having different aging periods. Korean J Food Nutr, 22, 548-553

19. Malherbe C, de Beer D, Joubert E (2012) Development of on-line high performance liquid chromatography
(HPLC)-biochemical detection methods as tools in the identification of bioactives. Int J Mol Sci, 13, 3101-3133

20. National Academy of Agricultural Science (2009) Tables of Food Functional Composition-agricultural \& food materials section, $1^{\text {st }}$ ed, National Academy of Agricultural Science, Suwon, Korea, p 1-450

21. de Beer D, Joubert E, Malherbe CJ, Brand DJ (2011) Use of countercurrent chromatography during isolation of 6-hydroxyluteolin-7-O-ß-glucoside, a major antioxidant of Athrixia phylicoides. J Chromatogr A, 1218, 6179-6186

22. Cakar UD, Petroric AV, Zivkovic MB, Vajs VE, Milovanvic MM, Zeravik J, Dordevic BI (2016) Phenolic profile of some fruit wines and their antioxidant properties. Hem Ind, 70, 661-672 